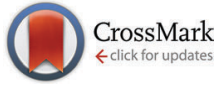

Cite this: New J. Chem., 2015, 39, 1013

Received (in Montpellier, France) 28th August 2014

Accepted 12th November 2014

DOI: 10.1039/c4nj01461h

www.rsc.org/njc

\title{
Synthesis of pyrite thin films and transition metal doped pyrite thin films by aerosol-assisted chemical vapour deposition + t
}

\author{
Sadia Khalid, ${ }^{\text {abc }}$ Ejaz Ahmed, ${ }^{a}$ M. Azad Malik, ${ }^{d}$ David J. Lewis, ${ }^{\text {cd }}$ Shahzad Abu Bakar, ${ }^{b}$ \\ Yaqoob Khan ${ }^{b}$ and Paul O'Brien*cd
}

\begin{abstract}
Diethyldithiocarbamato-metal complexes of the general formula $\left[\mathrm{M}\left(\mathrm{S}_{2} \mathrm{CN}(\mathrm{Et})_{2}\right)_{n}\right](\mathrm{M}=\mathrm{Fe}(I I), \mathrm{Co}(I I)), \mathrm{Ni}(I)$, $\mathrm{Cu}(I), \mathrm{Zn}(I)$ and $n=2,3)$ have been synthesized and used as precursors for the deposition of iron pyrite $\left(\mathrm{FeS}_{2}\right)$ and transition metal doped iron pyrite $\left(\mathrm{M}_{x} \mathrm{Fe}_{1-x} \mathrm{~S}_{2}\right)$ thin films on glass and indium tin oxide (ITO) coated glass substrates by aerosol assisted chemical vapour deposition (AACVD). Thermogravimetric analysis (TGA) confirmed that all the five complexes decompose into their corresponding metal sulfides. The iron complex $\left[\mathrm{Fe}\left(\mathrm{S}_{2} \mathrm{CNEt}_{2}\right)_{3}\right]$ (1) deposited pure cubic pyrite $\left(\mathrm{FeS}_{2}\right)$ films with granular crystallites at $350{ }^{\circ} \mathrm{C}$, whereas at $450{ }^{\circ} \mathrm{C}$ pyrite and marcasite were deposited. $\mathrm{M}_{x} \mathrm{Fe}_{1-x} \mathrm{~S}_{2}$ (where $\mathrm{M}=\mathrm{Co}, \mathrm{Ni}, \mathrm{Cu}, \mathrm{or} \mathrm{Zn}$ ) films were deposited by varying the relative concentration of complexes $\left[\mathrm{Fe}\left(\mathrm{S}_{2} \mathrm{CNEt}_{2}\right)_{3}\right](\mathbf{1})$ and $\left[\mathrm{Co}\left(\mathrm{S}_{2} \mathrm{CNEt}_{2}\right)_{3}\right]$ (2), $\left[\mathrm{Ni}\left(\mathrm{S}_{2} \mathrm{CNEt}_{2}\right)_{2}\right](3),\left[\mathrm{Cu}\left(\mathrm{S}_{2} \mathrm{CNEt}_{2}\right)_{2}\right](4)$ and $\left[\mathrm{Zn}\left(\mathrm{S}_{2} \mathrm{CNEt}_{2}\right)_{2}\right](\mathbf{5})$ at $350{ }^{\circ} \mathrm{C}$. The formation of a solid solution was confirmed by powder $X$-ray diffraction ( $p$-XRD). The surface morphology of the films was studied by scanning electron microscopy (SEM) whilst the height profiles of the films were revealed by atomic force microscopy (AFM). The elemental compositions of the films were confirmed by energy-dispersive $X$-ray (EDX) spectroscopy. To the best of our knowledge, these complexes are the first in their class to be used as single source precursors to deposit $\mathrm{M}_{x} \mathrm{Fe}_{1-x} \mathrm{~S}_{2}$ thin films.
\end{abstract}

\section{Introduction}

Iron pyrite $\left(\mathrm{FeS}_{2}\right)$ has germane properties for many applications, including photovoltaics, ${ }^{1}$ photodetectors, ${ }^{2}$ lithium ion battery cathodes, ${ }^{3}$ anodes for hydrogen production, ${ }^{4}$ photoelectrochemical cells (PECs), ${ }^{5}$ photocapacitors for energy conversion and storage ${ }^{6}$ as well as photocatalysis. ${ }^{7,8}$ Recent advances in synthetic methodology have allowed access to $\mathrm{FeS}_{2}$ nanostructures for biomedical applications of $\mathrm{FeS}_{2}$ including drug-delivery platforms. ${ }^{9}$

$\mathrm{FeS}_{2}$ has cubic (pyrite, $E_{\mathrm{g}}=0.95 \mathrm{eV}$ ) and metastable orthorhombic (marcasite, $E_{\mathrm{g}}=0.34 \mathrm{eV}$ ) polymorphs differing in their chemical structure by linking of Fe-centered octahedra. Pyrite is the most abundant of all metal sulfides with a high absorption

\footnotetext{
${ }^{a}$ Department of Physics, BahauddinZakariya University, Multan 60800, Pakistan

${ }^{b}$ Nanoscience and Catalysis Division, National Centre for Physics,

Quaid-i-Azam University Campus, Islamabad, 45320, Pakistan

${ }^{c}$ School of Chemistry, The University of Manchester, Oxford Road, Manchester, M13 9PL, UK

${ }^{d}$ School of Materials, The University of Manchester, Oxford Road, Manchester, M13 9PL, UK. E-mail: paul.o'brien@manchester.ac.uk; Fax: +44 (0)161 275 4616; Tel: $+44(0) 1612754653$

$\dagger$ This paper is dedicated to the late Dr Syed Tajammul Hussain.

\# Electronic supplementary information (ESI) available: EDX spectra of undoped and transition metal doped iron pyrite thin films. See DOI: 10.1039/c4nj01461 h
}

coefficient ( $\alpha \cong 5 \times 10^{5} \mathrm{~cm}^{-1}$ ) across the visible region of the electromagnetic spectrum $(\lambda<700 \mathrm{~nm})$, which is comparable with silicon. ${ }^{10}$ Thus pyrite, along with tin sulfide, ${ }^{11}$ copper zinc tin sulfide/selenide ${ }^{12}$ and inorganic-organic perovskites ${ }^{13}$ have attracted interest for use in sustainable photovoltaics. Pyrite devices display high quantum efficiencies of up to $90 \%$ but suffer from low open circuit voltages $\left(V_{\mathrm{OC}} \cong 200 \mathrm{mV}\right.$ ), which has been attributed to surface defects. ${ }^{14}$ The photovoltaic properties of pyrite can be improved by stronger interfacial interaction between donor-accepter layers ${ }^{15}$ or by tuning the bandgap by alloying. ${ }^{16}$ The alloying of iron pyrite $\left(\mathrm{FeS}_{2}\right)$ involves the random replacement of either Fe or $\mathrm{S}$ atoms with another cation $\left(\mathrm{M}_{x} \mathrm{Fe}_{1-x} \mathrm{~S}_{2}\right)$ or anion $\left(\mathrm{FeA}_{x} \mathrm{~S}_{2-x}\right)$ where $\mathrm{M}$ is a divalent metal cation and $\mathrm{A}$ is a divalent anion. As the degree of alloying increases, the material should begin to take on more of the electronic and physical properties associated with the alloying material.

Many metals have been doped into pyrite including $\mathrm{Mn},{ }^{17}$ $\mathrm{Co},{ }^{18} \mathrm{Ni},{ }^{19} \mathrm{Cu},{ }^{20} \mathrm{Zn},{ }^{21} \mathrm{Ti}^{22} \mathrm{Se}^{23} \mathrm{Sn},{ }^{24} \mathrm{Al}, \mathrm{P}, \mathrm{As},{ }^{25} \mathrm{Sb},{ }^{26} \mathrm{Cr}, \mathrm{Au}^{27}$ and $\mathrm{Nd}^{28}$ Hence, doping of metal cations into pyrite is facile and allows tailoring of the photovoltaic properties without greatly perturbing the structure of the host lattice thus avoiding the formation of thermodynamically unstable phases.

Thin films of ternary metal sulfides such as CuInS $2, \mathrm{AgInS}_{2}$, $\mathrm{AgBiS}_{2}$ have been widely applied in organic and inorganic $\mathrm{p}-\mathrm{n}$ 
junctions where they improve electrical properties ${ }^{29}$ compared with undoped metal sulfide thin films. $\mathrm{M}_{x} \mathrm{Fe}_{1-x} \mathrm{~S}_{2}$ systems in particular are known to have larger bandgaps than $\mathrm{FeS}_{2}$, which can make the materials attractive as window materials in heterojunction photovoltaic devices including pyrite organic, inorganic and hybrid solar cells. Recently, Mao et al. observed the reduction of dark currents by more than five times in a $\mathrm{Zn}_{x} \mathrm{Fe}_{1-x} \mathrm{~S}_{2}$ photoconductor. ${ }^{30}$

Transition metal doped pyrite thin films have been prepared by different physical and chemical vapour deposition routes including flash evaporation, ${ }^{31}$ chemical vapour transport (CVT) ${ }^{32}$ hydrothermal, ${ }^{33}$ solvothermal ${ }^{20}$ and electrodeposition. ${ }^{34}$ Several research groups have demonstrated the synthesis of doped iron pyrite with post-sulfuration of pre-deposited/precursor thin films. ${ }^{17,35-37}$ O'Brien and co-workers have widely demonstrated that a variety of inorganic complexes can be used as single source precursors for the preparation of various metal sulfide thin films,${ }^{38-43}$ including pyrite, ${ }^{44}$ as well as precursors to nanowires and nanorods, ${ }^{45,46}$ and nanoparticles. ${ }^{47,48}$ In particular, dithiocarbamato-metal complexes have been used to access a range of metal chalcogenides, including molybdenum disulfide ${ }^{49}$ and tin sulfide. ${ }^{11}$ Interestingly, mixtures of dithiocarbamate metal precursors can be used to access ternary materials such as copper zinc tin sulfide (CZTS). ${ }^{50}$

In this article we report the use of single source precursors $\left[\mathrm{Fe}\left(\mathrm{S}_{2} \mathrm{CNEt}_{2}\right)_{3}\right] \quad(\mathbf{1}), \quad\left[\mathrm{Co}\left(\mathrm{S}_{2} \mathrm{CNEt}_{2}\right)_{3}\right] \quad(2), \quad\left[\mathrm{Ni}\left(\mathrm{S}_{2} \mathrm{CNEt}_{2}\right)_{2}\right] \quad$ (3), $\left[\mathrm{Cu}\left(\mathrm{S}_{2} \mathrm{CNEt}_{2}\right)_{2}\right]$ (4) and $\left[\mathrm{Zn}\left(\mathrm{S}_{2} \mathrm{CNEt}_{2}\right)_{2}\right]$ (5) to deposit pyrite $\left(\mathrm{FeS}_{2}\right)$ and transition metal doped pyrite $\left(\mathrm{M}_{x} \mathrm{Fe}_{1-x} \mathrm{~S}_{2}\right.$ where $\mathrm{M}=\mathrm{Co}, \mathrm{Ni}, \mathrm{Cu}, \mathrm{Zn}$ ) crystalline thin films by AACVD at $350{ }^{\circ} \mathrm{C}$ onto glass and indium tin oxide (ITO) coated glass substrates. The deposited films do not require any external sulfur source or co-reagent for post sulfurization. AACVD is a potentially scaleable technique which could be used for mass-production of thin film solar cell absorber layers. The formation of $\mathrm{M}_{x} \mathrm{Fe}_{1-x} \mathrm{~S}_{2}$ thin films was investigated using p-XRD, SEM, EDX spectroscopy and AFM. To the best of our knowledge, these complexes are the first in their class to be used as single source precursors to deposit $\mathrm{M}_{x} \mathrm{Fe}_{1-x} \mathrm{~S}_{2}$ thin films.

\section{Experimental}

All synthesis was performed under an inert atmosphere of dry nitrogen using standard Schlenk techniques. All reagents were purchased from Sigma-Aldrich. Elemental analysis was performed by the University of Manchester micro-analytical service. Infrared spectra were recorded on a Specac single reflectance ATR instrument (4000-400 $\mathrm{cm}^{-1}$, resolution $4 \mathrm{~cm}^{-1}$ ). Melting points were recorded on a Barlo world SMP10 Melting Point Apparatus.

\section{Deposition of thin films by AACVD}

In a typical deposition, $0.3 \mathrm{~g}(0.6 \mathrm{mmol})$ of the iron precursor $(\mathbf{1})$ and varying mol\% of the dopant precursors (2-5) $(0.00 \mathrm{~mol} \%$, $0.05 \mathrm{~mol} \%$, $0.10 \mathrm{~mol} \%, 0.15 \mathrm{~mol} \%, 0.20 \mathrm{~mol} \%, 0.25 \mathrm{~mol} \%, 0.30$ $\mathrm{mol} \%$, where $\mathrm{mol} \%=([$ dopant precursor $] /([$ dopant precursor $]+$ [iron precursor]]) $\times 100 \%$ ), was dissolved in $15 \mathrm{~mL}$ tetrahydrofuran
(THF) in a two-necked $100 \mathrm{~mL}$ round-bottom flask with a gas inlet. The apparatus used for the deposition of $\mathrm{FeS}_{2}$ has been previously reported. ${ }^{51}$ Six glass or ITO substrates $\left(\sim 1-2 \mathrm{~cm}^{2}\right)$ were placed inside the reactor tube, which is placed in a Carbolite ${ }^{\circledR}$ furnace. The precursor solution was nebulised using a PIFCO ultrasonic humidifier (Model No. 1077). The aerosol droplets of the precursor generated were transferred into the hot wall zone of the reactor by the Ar gas (180-200 sccm). The argon flow rate was controlled by a Platon flow gauge.

\section{Characterization of thin films}

p-XRD studies were performed using a Bruker Xpert diffractometer equipped with a $\mathrm{Cu}-\mathrm{K} \alpha$ radiation source $(\lambda=1.5406 \AA$ ) $)$. The samples were mounted flat and scanned between $2 \theta=25^{\circ}$ and $65^{\circ}$ with a step size of $0.02^{\circ}$. Atomic force microscopy was carried using a Bruker Multimode 8 atomic force microscope, using a silicon nitride tip. Scanning electron microscopy was performed using a Philips XL30 FEG scanning electron microscope. EDX spectra were collected in the same microscope using a DX4 instrument and analysed using Espirit software. Films were carbon coated using an Edwards E306A coating system prior to SEM and EDX spectroscopy.

\section{Synthesis of precursors (1-5)}

Diethyldithiocarbamato transition metal complexes (1-5) were prepared as described previously. ${ }^{47}$ Brief synthetic details follow.

Tris(N,N-diethyldithiocarbamato)iron(III), $\left[\mathrm{Fe}\left(\mathrm{S}_{2} \mathrm{CN}(\mathrm{Et})_{2}\right)_{3}\right]$, (1). Potassium diethyldithiocarbamate was prepared as reported previously. ${ }^{52}$ Briefly, a mixture of $\mathrm{KOH}(2 \mathrm{~g}, 35.6 \mathrm{mmol})$ in ethanol $(50 \mathrm{~mL})$ was stirred in a three neck flask for 20 minutes. Diethylamine $(3.68 \mathrm{~mL}, 35.6 \mathrm{mmol})$ was added to this solution and stirred for 30 minutes. Carbon disulfide $(2.15 \mathrm{~mL}, 35.6 \mathrm{mmol})$ was added drop wise to this solution and stirred for 2-3 h.

To this solution, a freshly prepared solution of iron nitrate nonahydrate $\left(\mathrm{Fe}\left(\mathrm{NO}_{3}\right)_{3} \cdot 9 \mathrm{H}_{2} \mathrm{O}\right)(2.96 \mathrm{~g}, 7.3 \mathrm{mmol})$ in ethanol $(50 \mathrm{~mL})$ was added drop wise to the reaction mixture by a dropping funnel. The reaction mixture was stirred for 5-6 h. Black precipitate was formed which was filtered, washed with an ethanol-water mixture and dried under atmospheric pressure. mpt: $257-260^{\circ} \mathrm{C}$. Elemental analysis: calc: C, 35.90; H, 6.04; N, 8.39; S, 38.40; Fe, 11.15\%. Found: C, 35.89; H, 6.32; N, 8.29; S, 38.61; Fe, $10.89 \%$. FTIR $\left(\nu_{\max } \mathrm{cm}^{-1}\right): 2973.11(\mathrm{w}), 1484.38(\mathrm{~s}), 1372.54(\mathrm{~s})$, 1266.81(s), 1206.35(s), 1132.34(s), 1071.96(s), 992.78(s), 911.79(s), 844.35(s), 782.56(s). See Fig. S11 (1), ESI.\$

Tris(N,N-diethyldithiocarbamato)cobalt(III), $\left[\mathrm{Co}\left(\mathrm{S}_{2} \mathrm{CN}(\mathrm{Et})_{2}\right)_{3}\right],(2)$. Complex (2) was prepared with the same method but using cobalt nitrate hexahydrate $\left(\mathrm{Co}\left(\mathrm{NO}_{3}\right)_{2} \cdot 6 \mathrm{H}_{2} \mathrm{O}\right)(2.08 \mathrm{~g}$, $7.15 \mathrm{mmol})$. mpt: 262-265 ${ }^{\circ} \mathrm{C}$. Elemental analysis: calc: $\mathrm{C}, 35.77 ; \mathrm{H}, 6.00$; N, 8.34; S, 38.19; Co, 11.87\%. Found: C, 34.79; H, 6.19; N, 8.03; S, 37.64; Co, $11.87 \%$. FTIR $\left(\nu_{\max } \mathrm{cm}^{-1}\right)$ : 2971.90(w), 1482.77(s), 1431.82(s), 1263.69(s), 1211.19(s), 1132.76(s), 1074.81(s), 997.30(s), 913.28(s), 849.35(s), 783.95(s). See Fig. S11 (2), ESI.\$

$\operatorname{Bis}\left(N, N\right.$-diethyldithiocarbamato)nickel(II), $\left[\mathrm{Ni}\left(\mathrm{S}_{2} \mathrm{CN}(\mathrm{Et})_{2}\right)_{2}\right]$, (3). Complex (3) was prepared by using nickel nitrate hexahydrate $\left(\mathrm{Ni}\left(\mathrm{NO}_{3}\right)_{2} \cdot 6 \mathrm{H}_{2} \mathrm{O}\right)(2.06 \mathrm{~g}, 7.08 \mathrm{mmol})$. mpt: $227-232{ }^{\circ} \mathrm{C}$. Elemental analysis: calc: C, 33.81; H, 5.68; N, 7.89; S, 36.11; Ni, $16.52 \%$. 
Found: C, 34.06; H, 5.68; N, 7.92; S, 36.43; Ni, 15.07\%. FTIR $\left(\nu_{\max } \mathrm{cm}^{-1}\right):$ 2972.39(w), 1515.70(s), 1431.57(s), 1376.15(s), 1352.12(s), 1298.98(s), 1274.06(s), 1204.67(s), 1152.95(s), 1075.98(s), 991.90(s), 911.90(s), 849.41(s), 780.14(s). See Fig. S11 (3), ESI.

$\operatorname{Bis}\left(N, N\right.$-diethyldithiocarbamato)copper(II), $\left[\mathrm{Cu}\left(\mathrm{S}_{2} \mathrm{CN}(\mathrm{Et})_{2}\right)_{2}\right]$, (4). Complex (4) was prepared by the same procedure using copper nitrate trihydrate $\left(\mathrm{Cu}\left(\mathrm{NO}_{3}\right)_{2} \cdot 3 \mathrm{H}_{2} \mathrm{O}\right)(1.72 \mathrm{~g}, 7.12 \mathrm{mmol})$. mpt: $188-194{ }^{\circ} \mathrm{C}$. Elemental analysis: calc: C, 33.35; H, 5.60; N, 7.78; S, 35.62; Cu, 17.65\%. Found: C, 34.26; H, 5.89; N, 7.88; $\mathrm{S}, 36.46 ; \mathrm{Cu}, 16.02 \%$. FTIR $\left(\nu_{\max } \mathrm{cm}^{-1}\right): 2971.99(\mathrm{w}), 1500.88(\mathrm{~s})$, 1434.35(s), 1350.68(s), 1299.31(s), 1270.77(s), 1205.70(s), 1145.33(s), 1095.33(s), 1070.81(s), 994.98(s), 912.11(s), 845.78(s), 777.91(s). See Fig. S11 (4), ESI.

$\operatorname{Bis}\left(\boldsymbol{N}, \boldsymbol{N}\right.$-diethyldithiocarbamato)zinc, $\left[\mathrm{Zn}\left(\mathrm{S}_{2} \mathrm{CN}(\mathrm{Et})_{2}\right)_{2}\right]$, (5). Complex (5) was prepared by adopting same procedure by using zinc nitrate hexahydrate $\left(\mathrm{Zn}\left(\mathrm{NO}_{3}\right)_{2} \cdot 6 \mathrm{H}_{2} \mathrm{O}\right)(2.12 \mathrm{~g}, 7.13 \mathrm{mmol})$. mpt: $175-180{ }^{\circ} \mathrm{C}$. Elemental analysis: calc: C, 33.18; H, 5.57; N, 7.74; S, 35.44; Zn, 18.07\%. Found: C, 33.44; H, 5.71; N, 7.77; S, 35.57; Zn, 17.69\%. FTIR ( $\left.\nu_{\max } \mathrm{cm}^{-1}\right): 2965.85(\mathrm{w}), 1498.47(\mathrm{~s})$, 1426.28(s), 1376.45(s), 1352.13(s), 1296.39(s), 1269.27(s), 1199.48(s), 1143.26(s), 1070.11(s), 990.75(s), 910.23(s), 838.29(s), 775.97(s). See Fig. S11 (5), ESI.+

\section{Results and discussion}

Diethyldithiocarbamate complexes were synthesized by the reaction of ethanolic solutions of the requisite transition metal salt with potassium diethyldithiocarbamate generated in situ in ethanol. All the complexes are air and moisture stable. Complexes (1), (2), (3), (4), and (5) are soluble in toluene, tetrahydrofuran, chloroform, and other organic solvents.

\section{Thermogravimetric analysis}

Thermogravimetric analysis (TGA) generate weight\% vs. temperature plots and thus gives insight into the decomposition and/or volatility of the complexes by observing weight lost by precursor complexes as temperature increases. TGA analysis of the complexes in Fig. 1 demonstrates that $\left[\mathrm{Fe}\left(\mathrm{S}_{2} \mathrm{CNEt}_{2}\right)_{3}\right](\mathbf{1})^{53}$ and $\left[\mathrm{Zn}\left(\mathrm{S}_{2} \mathrm{CNEt}_{2}\right)_{2}\right]$ (5) decompose in a single step whilst $\left[\mathrm{Co}\left(\mathrm{S}_{2} \mathrm{CNEt}_{2}\right)_{3}\right]$ (2), $\left[\mathrm{Ni}\left(\mathrm{S}_{2} \mathrm{CNEt}_{2}\right)_{2}\right](3)$ and $\left[\mathrm{Cu}\left(\mathrm{S}_{2} \mathrm{CNEt}_{2}\right)_{2}\right]$ (4) decompose in two steps. The first decomposition step in $\left(\left[\mathrm{Co}\left(\mathrm{S}_{2} \mathrm{CNEt}_{2}\right)_{3}\right](2)\right.$ is small compared with the other complexes studied. Additionally, $\left[\mathrm{Fe}\left(\mathrm{S}_{2} \mathrm{CNEt}_{2}\right)_{3}\right](\mathbf{1}),\left[\mathrm{Co}\left(\mathrm{S}_{2} \mathrm{CNEt}_{2}\right)_{3}\right](2),\left[\mathrm{Ni}\left(\mathrm{S}_{2} \mathrm{CNEt}_{2}\right)_{2}\right](3)$, $\left[\mathrm{Cu}\left(\mathrm{S}_{2} \mathrm{CNEt}_{2}\right)_{2}\right](4)$ and $\left[\mathrm{Zn}\left(\mathrm{S}_{2} \mathrm{CNEt}_{2}\right)_{2}\right]$ (5) display rapid weight loss between 254 and $337^{\circ} \mathrm{C}, 243$ and $380{ }^{\circ} \mathrm{C}, 255$ and $378{ }^{\circ} \mathrm{C}$, 241 and $335{ }^{\circ} \mathrm{C}$, and 222 and $342{ }^{\circ} \mathrm{C}$ respectively (Fig. 1). The observed weights of the final residues are $21.09 \%$ for $(1), 18.98 \%$ for (2), 3.54\% for (3), $22.12 \%$ for (4), and $4.59 \%$ for (5) respectively. All these transition metal complexes (1-5) on heating in nitrogen atmosphere decompose to form the corresponding metal sulfide. The calorimetric response of the complexes showed similar behaviour in the DSC plots (Fig. S6-S10, ESI ). There are sharp endothermic peaks between $180-280{ }^{\circ} \mathrm{C}$ and broad exothermic peaks between $200-600{ }^{\circ} \mathrm{C}$. The first endothermic peak corresponds to the melting of the complexes while the second represent

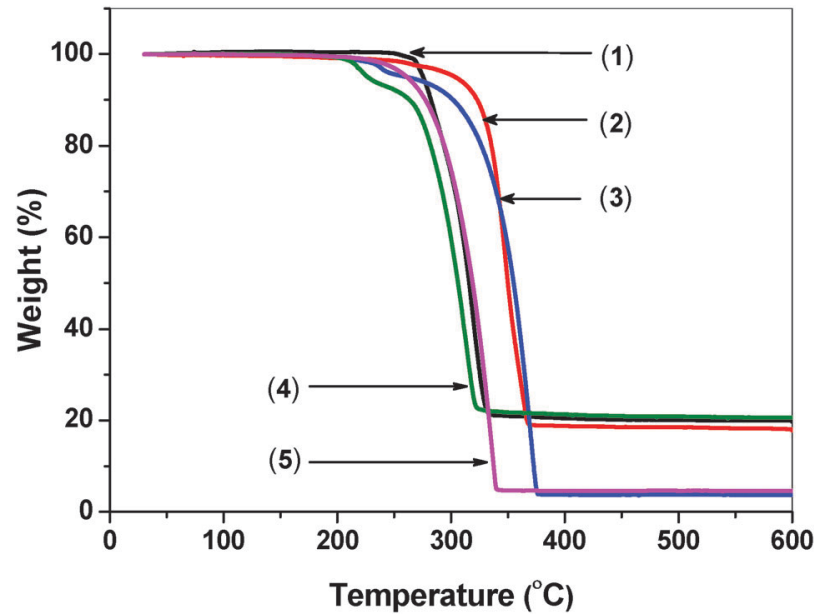

Fig. 1 TGA of transition metals complexes $\left[\mathrm{Fe}\left(\mathrm{S}_{2} \mathrm{CNEt}_{2}\right)_{3}\right](\mathbf{1}),\left[\mathrm{Co}\left(\mathrm{S}_{2} \mathrm{CNEt}_{2}\right)_{3}\right]$ (2), $\left[\mathrm{Ni}\left(\mathrm{S}_{2} \mathrm{CNEt}_{2}\right)_{2}\right](\mathbf{3}),\left[\mathrm{Cu}\left(\mathrm{S}_{2} \mathrm{CNEt}_{2}\right)_{2}\right](\mathbf{4})$ and $\left[\mathrm{Zn}\left(\mathrm{S}_{2} \mathrm{CNEt}_{2}\right)_{2}\right]$ (5).

their decomposition to form the respective metal sulfides. A prominent feature of the DSC peaks is the progressive decrease in temperature with increase in atomic number for a particular metal ion. This trend could be attributed to the increase in molecular weight and also, the increase in the size of the central metal ion respectively. A reduction trend is also observed in the broad exothermic peaks of complexes. It is apparent that two different steps of decomposition are associated with the degradation of the complex and the residue, the latter being an oxidation reaction. From the results of the TGA/DSC, one can assign the order of the complexes in terms of decreasing stability as follows: $\mathrm{Zn}<\mathrm{Cu}<\mathrm{Ni}<\mathrm{Co}<$ Fe. Fig. S6-S10 (ESI

\section{Structural studies}

The powder XRD patterns of the as deposited films at $350{ }^{\circ} \mathrm{C}$ (Fig. 2(b)) show solely the cubic pyrite phase $\left(\mathrm{FeS}_{1.96}\right.$ (ICDD No. 01-073-8127)). It was possible to index the Bragg reflections from the ( $h k l$ ) planes to the (111), (200), (210), (220), (311), (222), (023) and (321) planes. The weak reflection at $25.92^{\circ}$ and $52.31^{\circ}$

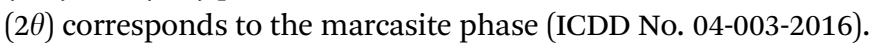
The p-XRD patterns of the as -deposited films at $450{ }^{\circ} \mathrm{C}$ (Fig. 2(c)) show mixed phases of iron sulfide hexagonal pyrrhotite-IT $\left(\mathrm{Fe}_{0.9} 5 \mathrm{~S}_{1.05}\right.$ (ICDD No. 01-075-0600)) and hexagonal troilite (ICDD No. 00-004-0832). The major diffraction peaks for hexagonal pyrrhotite-IT could be indexed to the (100), (101), (102) and (103) planes. The major diffraction peaks for hexagonal troilite (ICDD No. 00-004-0832) could be indexed to the (201), (211), (220) planes with a minor peak attributed to marcasite observed at $37.13^{\circ}$ (ICDD No. 04-003-2016).

\section{Morphological studies}

SEM images of films deposited at $350{ }^{\circ} \mathrm{C}$ show sheet-like crystallites (Fig. 3) with a size range of 1-2 $\mu \mathrm{m}$. The high magnification images shows that the sponge like structures are composed of nanoparticles with sizes around $30-50 \mathrm{~nm}$. Analysis of the films using EDX spectroscopy suggests an iron : sulfur ratio of $48: 52$ at $350{ }^{\circ} \mathrm{C}$ (Fig. S1, ESI $\ddagger$ ). This difference in stoichiometry could 


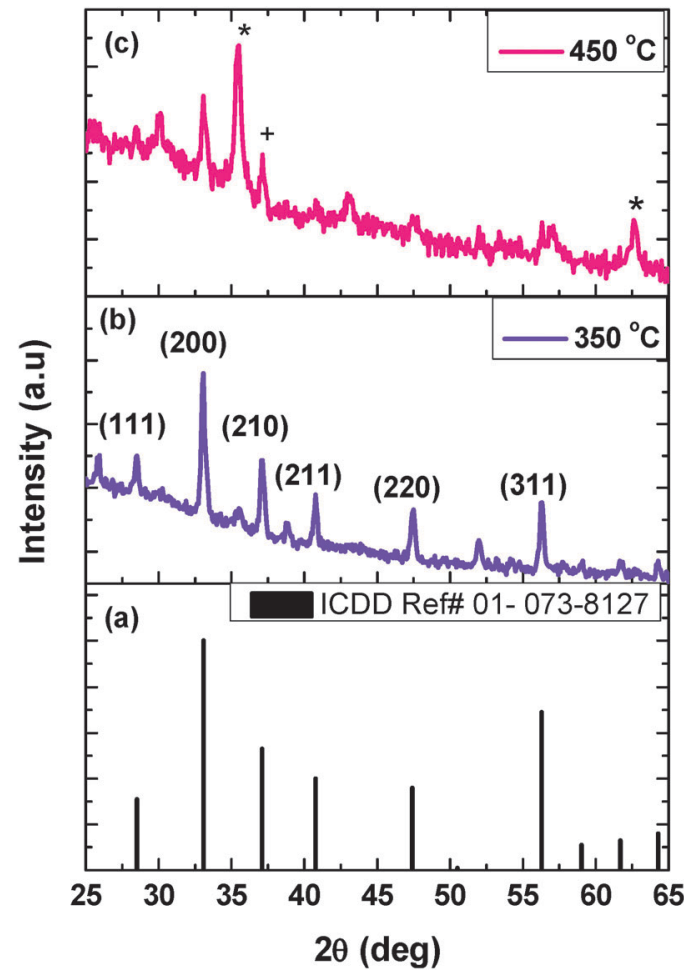

Fig. 2 (a) Standard p-XRD patterns of iron sulfide (pyrite FeS 1.96 (ICDD No. 01-073-8127)) and thin films deposited from complex (1) on glass substrate at (b) $350{ }^{\circ} \mathrm{C}$, (c) $450{ }^{\circ} \mathrm{C}$. The (+) shows troilite and (*) pyrrhotite (FeS) phases.

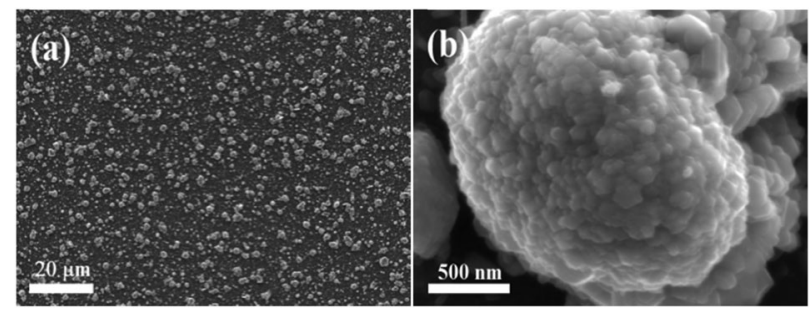

Fig. 3 Secondary electron SEM images $(10 \mathrm{kV})$ of pyrite $\left(\mathrm{FeS}_{2}\right)$ thin films deposited from complex (1) on a glass substrate by AACVD at $350^{\circ} \mathrm{C}$.

potentially be attributed to contribution of iron content in glass substrates ${ }^{35}$ due to the large interaction volume of electrons at $20 \mathrm{kV}$ accelerating voltage during EDX spectroscopy.

\section{Transition metal doped pyrite $\left(\mathrm{M}_{x} \mathrm{Fe}_{1-x} \mathrm{~S}_{2}\right)$ thin films}

TGA studies confirmed that dopant precursors (2-5) decompose to the corresponding metal sulfides in similar range of temperatures to the iron precursor (1). ${ }^{54}$ Thus the dopant precursors fulfil the design requirement for deposition of $\mathrm{M}_{x} \mathrm{Fe}_{1-x} \mathrm{~S}_{2}$ by AACVD in that their decomposition temperatures are commensurate with that of (1) so that decomposition of both the iron and dopant precursors occurs simultaneously and thus control of the dopant level in $\mathrm{M}_{x} \mathrm{Fe}_{1-x} \mathrm{~S}_{2}$ films can be controlled to an extent by the amount of the precursor in the flask prior to nebulisation. $\mathrm{M}_{x} \mathrm{Fe}_{1-x} \mathrm{~S}_{2}$ films were deposited by AACVD at $350{ }^{\circ} \mathrm{C}$ by varying the ratio of complexes (1) and (2), (3), (4), and (5) in the delivery solution; $x$ is the mole fraction of transition metals in this vessel throughout this section, assuming $100 \%$ incorporation of dopant. The deposited films were grey and uniform over the substrates at $0.3 \mathrm{mmol}$ of iron complex (1). Similar films were deposited using complexes (1) and (2), (1) and (3), (1) and (4), and (1) and (5) with varying ratio of precursors (2), (3), (4), and (5) $(0.05 \mathrm{~mol} \%, 0.1 \mathrm{~mol} \%, 0.15 \mathrm{~mol} \%, 0.20 \mathrm{~mol} \%, 0.25 \mathrm{~mol} \%$, $0.30 \mathrm{~mol} \%$ ) and keeping (1) constant at $0.3 \mathrm{mmol}$.

\section{Structural studies}

AACVD using complex (1) at $350{ }^{\circ} \mathrm{C}$ gives predominantly cubic $\mathrm{FeS}_{2}$ films by powder XRD (p-XRD). Doped pyrite $\mathrm{M}_{x} \mathrm{Fe}_{1-x} \mathrm{~S}_{2}$ films were also characterized by pXRD. p-XRD patterns of $\mathrm{M}_{x} \mathrm{Fe}_{1-x} \mathrm{~S}_{2}$ films deposited on glass/ITO substrates were recorded. Both $\mathrm{FeS}_{2}$ and $\mathrm{CoS}_{2}$ crystallize in the pyrite structure and this should constitute a continuous solid solution $\mathrm{Co}_{x} \mathrm{Fe}_{1-x} \mathrm{~S}_{2}{ }^{55}$ The diffraction peak intensity of the cubic pyrite (200) plane varies with the doping concentration of cobalt complex (2) (Fig. 4). The doping of cobalt does not change the cubic crystal structure of $\mathrm{FeS}_{2}$ but causes a peak shift that is prominent in cobalt doped pyrite $\left(\mathrm{Co}_{x} \mathrm{Fe}_{1-x} \mathrm{~S}_{2}\right)$ thin films for the (200) plane from $2 \theta=33.05^{\circ}$ (for $0.00 \mathrm{~mol} \%$ ) to $2 \theta=32.94^{\circ}$ (for $\left.0.30 \mathrm{~mol} \%\right)^{18}$ No other impurity phases were observed in p-XRD patterns except in doped samples for $0.30 \mathrm{~mol} \%$ at $2 \theta=35.59^{\circ}$ which can be indexed to $\mathrm{CoFeS}_{2}$ (ICDD No. 01-075-0607).

Solubility of NiS in $\mathrm{FeS}_{2}$ is very low from the phase diagram of the Fe-Ni-S system. ${ }^{56,57}$ However, nickel doping causes the lattice expansion of the crystal lattice in $\mathrm{Ni}_{x} \mathrm{Fe}_{1-x} \mathrm{~S}_{2}$ as previously reported $;^{56}$ the reflection for the (200) plane shifts from $33.05^{\circ}$ ( $0.00 \mathrm{~mol} \%)$ to $32.99^{\circ}$ (0.30 mol\%) (Fig. 5). Diffraction peaks are also observed at $2 \theta(h k l)=30.10^{\circ}(220), 35.49^{\circ}(400), 38.87^{\circ}(331)$, and $51.98^{\circ}$ (440) which can be indexed to nickel iron sulfide $\left(\mathrm{Fe}_{9} \mathrm{Ni}_{9} \mathrm{~S}_{16}\right.$ ) (ICDD No. 01-075-2024) (for $0.05 \mathrm{~mol} \%$ ).

Copper-doped iron sulfide $\mathrm{Cu}_{x} \mathrm{Fe}_{1-x} \mathrm{~S}_{2}$ thin films from a mixture of complexes (1) and (4) were deposited by AACVD at

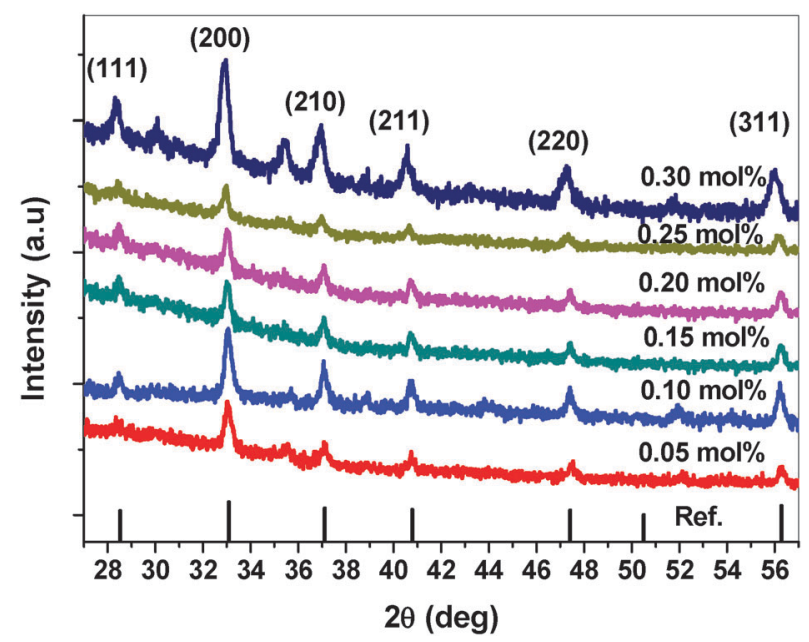

Fig. 4 p-XRD patterns of cobalt doped iron sulfide $\mathrm{Co}_{x} \mathrm{Fe}_{1-x} \mathrm{~S}_{2}$ thin films deposited from complexes (1) and (2) at $350{ }^{\circ} \mathrm{C}$ on glass substrate synthesised by AACVD with different starting ratio of cobalt complex (2). 


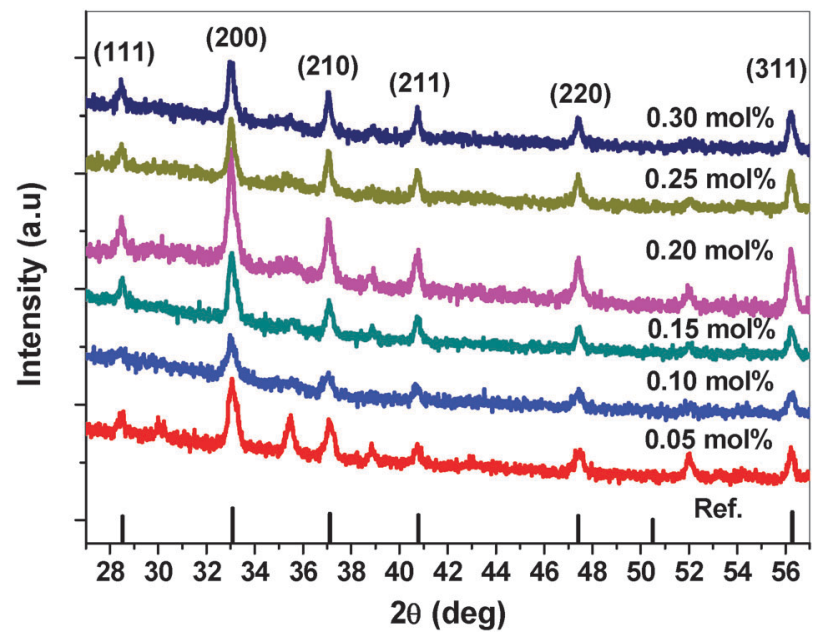

Fig. 5 p-XRD patterns of nickel doped iron sulfide $\mathrm{Ni}_{x} \mathrm{Fe}_{1-x} \mathrm{~S}_{2}$ thin films deposited from complexes (1) and (3) at $350{ }^{\circ} \mathrm{C}$ on glass substrate by $A A C V D$, showing the effect of varying mol\% of nickel complex (3) in the precursor solution.

$350{ }^{\circ} \mathrm{C}$ on glass/ITO substrate with varying starting mol\% of the copper complex. Wang et al. have used these complexes to synthesise $\mathrm{CuFeS}_{2}$ nanocrystals utilizing a facile solution based method. ${ }^{58}$ The preferred orientation of crystallites in the (200) and (311) planes increases with an increased molar concentration of copper complex $(0.10 \mathrm{~mol} \%){ }^{20}$ The gradual increase in doping level of copper changes the crystal structure of $\mathrm{FeS}_{2}$ (Fig. 6); the major $\mathrm{FeS}_{2}$ reflection for the (200) plane shifts from $2 \theta=33.05^{\circ}$ to $2 \theta=32.98^{\circ}$ up to $0.15 \mathrm{~mol} \%$ and other peaks appears at $2 \theta=29.46^{\circ}(112), 49.20^{\circ}(204), 58.10^{\circ}$ (116) that can be assigned to $\mathrm{CuFeS}_{2}$ (chalcopyrite-ICDD No. 01-083-0984) phase (for $0.30 \mathrm{~mol} \%$ ). ${ }^{59}$

Zinc-doped pyrite thin films exhibited the cubic pyrite structure by $\mathrm{p}$-XRD. The intensity of diffraction peak for the

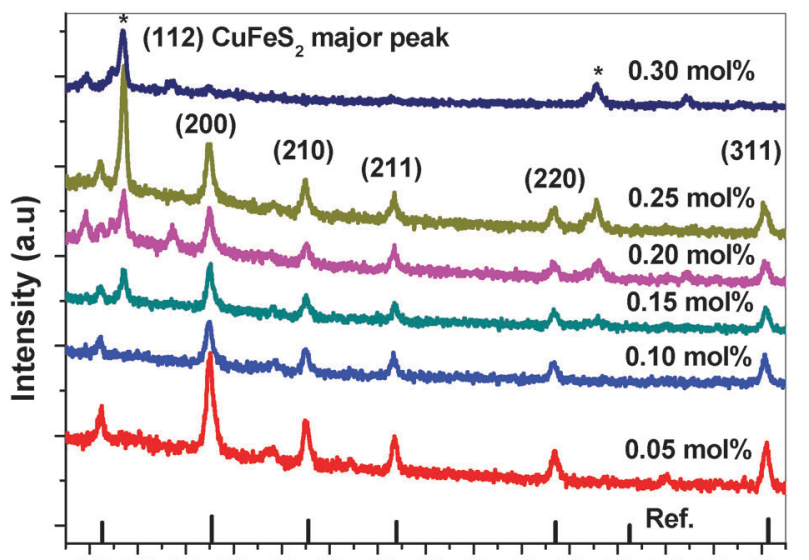

$\begin{array}{lllllllllllllll}28 & 30 & 32 & 34 & 36 & 38 & 40 & 42 & 44 & 46 & 48 & 50 & 52 & 54 & 56\end{array}$

\section{$2 \theta$ (deg)}

Fig. 6 p-XRD patterns of copper doped iron sulfide $\mathrm{Cu}_{x} \mathrm{Fe}_{1-x} \mathrm{~S}_{2}$ thin films deposited from complexes (1) and (4) at $350{ }^{\circ} \mathrm{C}$ on glass substrate by AACVD, showing the effect of varying mol\% of copper complex (4) in the precursor solution.

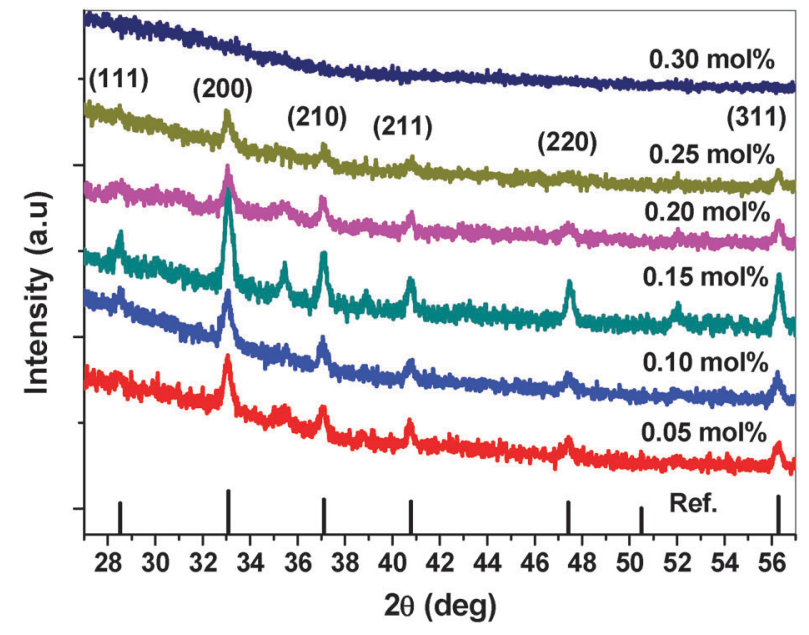

Fig. $7 \mathrm{p}$-XRD patterns of zinc doped iron sulfide $\mathrm{Zn}_{x} \mathrm{Fe}_{1-x} \mathrm{~S}_{2}$ thin films deposited from complexes (1) and (5) at $350{ }^{\circ} \mathrm{C}$ on glass substrate by AACVD, showing the effect of varying mol\% of zinc complex (5) in the precursor solution.

preferred orientation of crystallites along (200) plane increases with an increased dopant molar concentration (Fig. 7). After $0.15 \mathrm{~mol} \%$, diffraction peaks at $2 \theta=25.71^{\circ}, 35.50^{\circ}, 52.07^{\circ}$ are observed that may be assigned to hexagonal phase $\mathrm{ZnS}$ (ICDD No. 01-072-0163). ${ }^{60}$ The (200) reflection in $\mathrm{Zn}_{x} \mathrm{Fe}_{1-x} \mathrm{~S}_{2}$ thin films exhibits a shift from $2 \theta=33.05^{\circ}(0.00 \mathrm{~mol} \%)$ to $2 \theta=32.96^{\circ}$ (0.30 mol\%) (Fig. 7), an observation that is also supported by previous literature on zinc doped pyrite. ${ }^{30}$ It can also be observed that with the increase in dopant concentration, the diffraction intensity decreases gradually and no reflections appear in the XRD pattern of the films deposited with $0.30 \mathrm{~mol} \%$ of $\mathrm{Zn}$ complex. Previous studies ${ }^{61}$ show that increased incorporation of $\mathrm{Zn}^{+2}$ leads to an increased structural disorder in the host lattice which may result in reduced grain sizes to release the lattice strain and lowering in diffraction intensity.

Behaviour of the different pair of complexes from $0.10 \mathrm{~mol} \%$ to $0.30 \mathrm{~mol} \%$ shows a trend for each dopant and concentration of dopant (Fig. 8). This trend may be due to slight change of decomposition temperature, volatility of precursors or due to difference in solubility of precursors in THF with variable concentration. By analysing $\mathrm{p}$-XRD data, it is also observed that all transition metal doped pyrite thin films $\mathrm{M}_{x} \mathrm{Fe}_{1-x} \mathrm{~S}_{2}$ exhibit pyrite type cubic crystal structure for combination of precursors (1):(2), (1):(3) and (1):(5). There is a change in crystal lattice from cubic to tetragonal $\left(\mathrm{FeS}_{2}\right.$ to $\mathrm{CuFeS}_{2}$ ) for the combination of complexes (1):(4). It is concluded from above observation that the value of the lattice constant $a$ of transition metal doped iron pyrite thin films increases as the doping concentration of transition metal increases. Consequently, substitution of transition metal ions $\left(\mathrm{M}^{2+}\right)$ with larger ionic radii in the $\mathrm{Fe}^{2+}$ positions causes lattice expansion. The lattice expansion may also arise due to the occupancy of the transition metal atoms in placement of iron vacancies in the pyrite lattice. Similar results were observed in case of other impurities. ${ }^{62}$ 


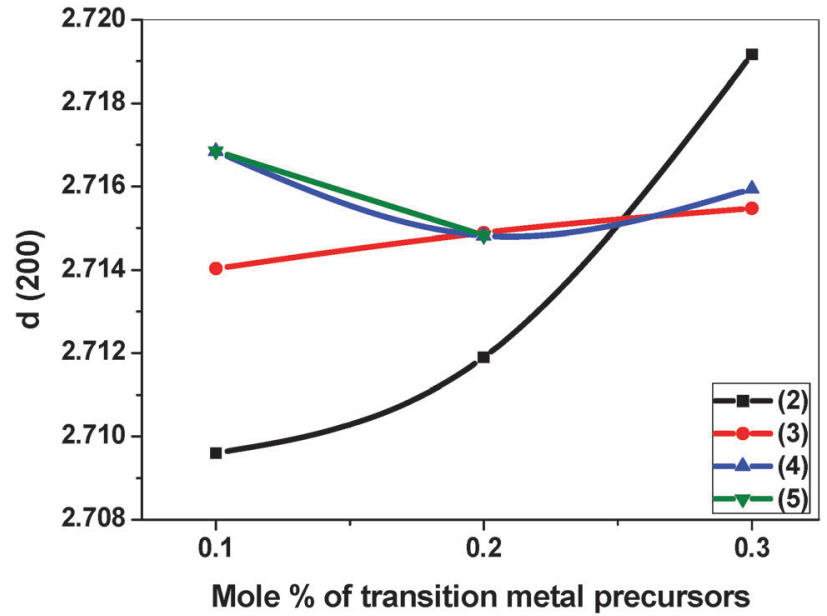

Fig. $8 d_{(200)}$ (in Ångstroms) vs. mol\% of complexes (2-5) for transition metal doped pyrite thin films $\left(\mathrm{M}_{x} \mathrm{Fe}_{1-x} \mathrm{~S}_{2}\right)$.

The Scherrer eqn (1), was used to calculate crystallite size, $D$.

$$
D=\frac{0.9 \lambda}{B \cos \theta_{B}}
$$

where $\lambda$ is the X-ray wavelength $(\lambda=1.5406 \AA)$ and $B$ is the full width at half-maximum (FWHM) of the (200) peak. Average particle sizes were calculated to be $33 \mathrm{~nm}, 34 \mathrm{~nm}, 36 \mathrm{~nm}$ and $28 \mathrm{~nm}$ for cobalt, nickel, copper and zinc doped pyrite thin films respectively (Fig. 9).

\section{Morphological studies}

Transition metal $(0.10 \mathrm{~mol} \%)$ doped pyrite $\left(\mathrm{M}_{x} \mathrm{~F}_{1-x} \mathrm{~S}_{2}\right)$ thin films deposited on ITO-coated glass substrates at $350{ }^{\circ} \mathrm{C}$ using precursor (1) in combination with precursors (2), (3), (4) \& (5) were imaged by SEM in secondary electron mode with an accelerating voltage of $10 \mathrm{kV}$. Granular structures were observed in cobalt (Fig. 10(a) and (b)) and nickel doped pyrite thin films (Fig. 10(c) and (d)) with average size $20-50 \mathrm{~nm}$. Rhombohedral structures

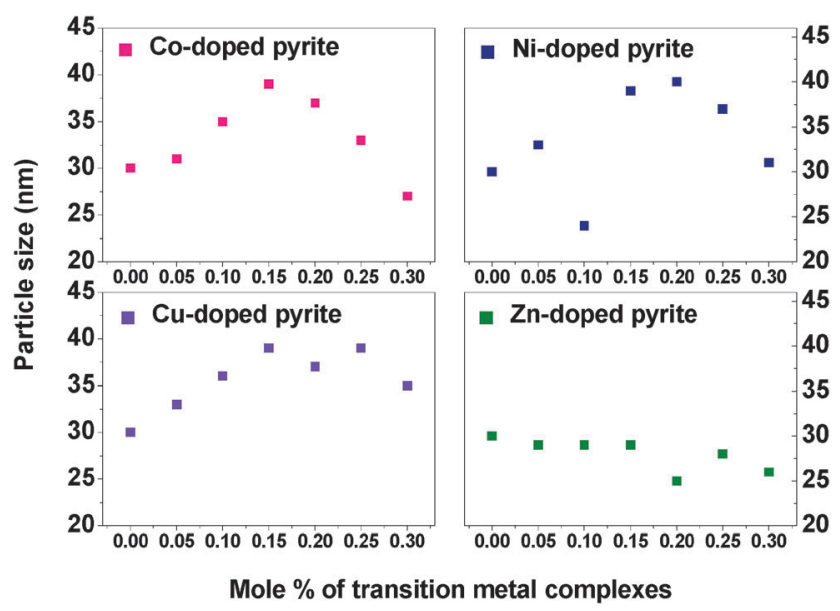

Fig. 9 Average particle size of transition metal doped pyrite thin films as a function of metal dopant concentration in mol\%, calculated using the Scherrer equation.
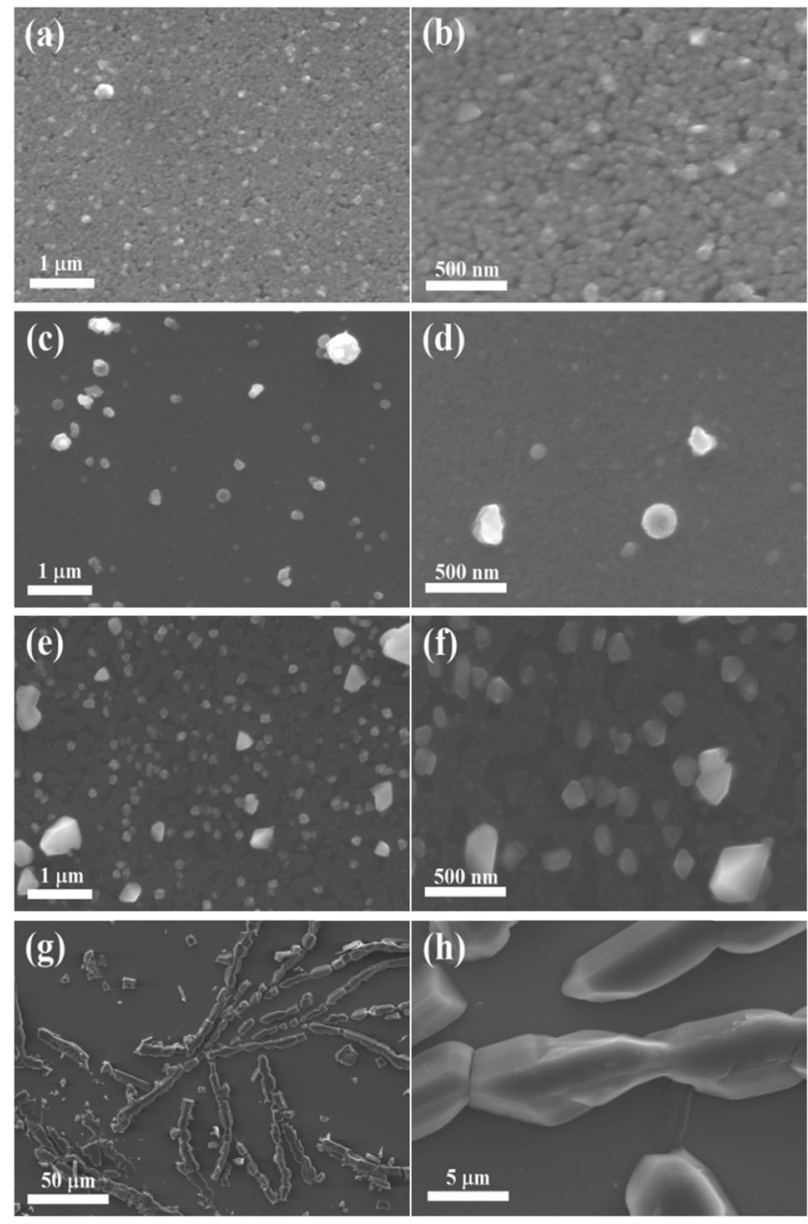

Fig. 10 Secondary electron mode SEM images $(10 \mathrm{kV})$ of transition metal doped pyrite $\left(\mathrm{M}_{x} \mathrm{Fe}_{1-x} \mathrm{~S}_{2}\right)$ thin films deposited at $350{ }^{\circ} \mathrm{C}$ on ITO-coated glass substrates by AACVD from complexes (a, b) (1) and (2), (c, d) (1) and (3) (e, f) (1) and (4) (g, h): (1) and (5).

were observed with average size $0.2-0.5 \mu \mathrm{m}$ for the copper dopant (Fig. 10(e) and (f)). Chain like rhombohedral structures were observed with average size $2-5 \mu \mathrm{m}$ for zinc doped pyrite thin films (Fig. $10(\mathrm{~g})$ and $(\mathrm{h})$. The morphology of the films strongly depends on the substrates that provide a base for nanostructures and experimental conditions used to deposit thin films.

Additionally, transition metal doped pyrite $\left(\mathrm{M}_{x} \mathrm{Fe}_{1-x} \mathrm{~S}_{2}\right)$ thin films deposited on glass substrates at $350^{\circ} \mathrm{C}$ by using precursor (1) in combination with complexes (2), (3), (4) \& (5) were imaged by secondary electron SEM at different magnifications. Clusters of floret-like crystallites were deposited with average diameter size from $1-2 \mu \mathrm{m}$ at $0.05 \mathrm{~mol} \%$ of cobalt doping (Fig. 11(a) and (b)). Hexagonal discs like crystallites were deposited with average diameter size of $0.5-1 \mu \mathrm{m}$ at $0.10 \mathrm{~mol} \%$ of cobalt dopant (Fig. 11(c) and (d)). Granular cluster like morphology of films were deposited using $0.15 \mathrm{~mol} \%$ of cobalt doping (Fig. 11(e) and (f)). Cluster of hexagonal plates were deposited with an average diameter of $0.5-1 \mu \mathrm{m}$ using $0.20 \mathrm{~mol} \%$ of cobalt doping (Fig. 11(g) and (h)). Clusters of floret-like crystallites with average diameter size from $250 \mathrm{~nm}$ for $0.30 \mathrm{~mol} \%$ of nickel 

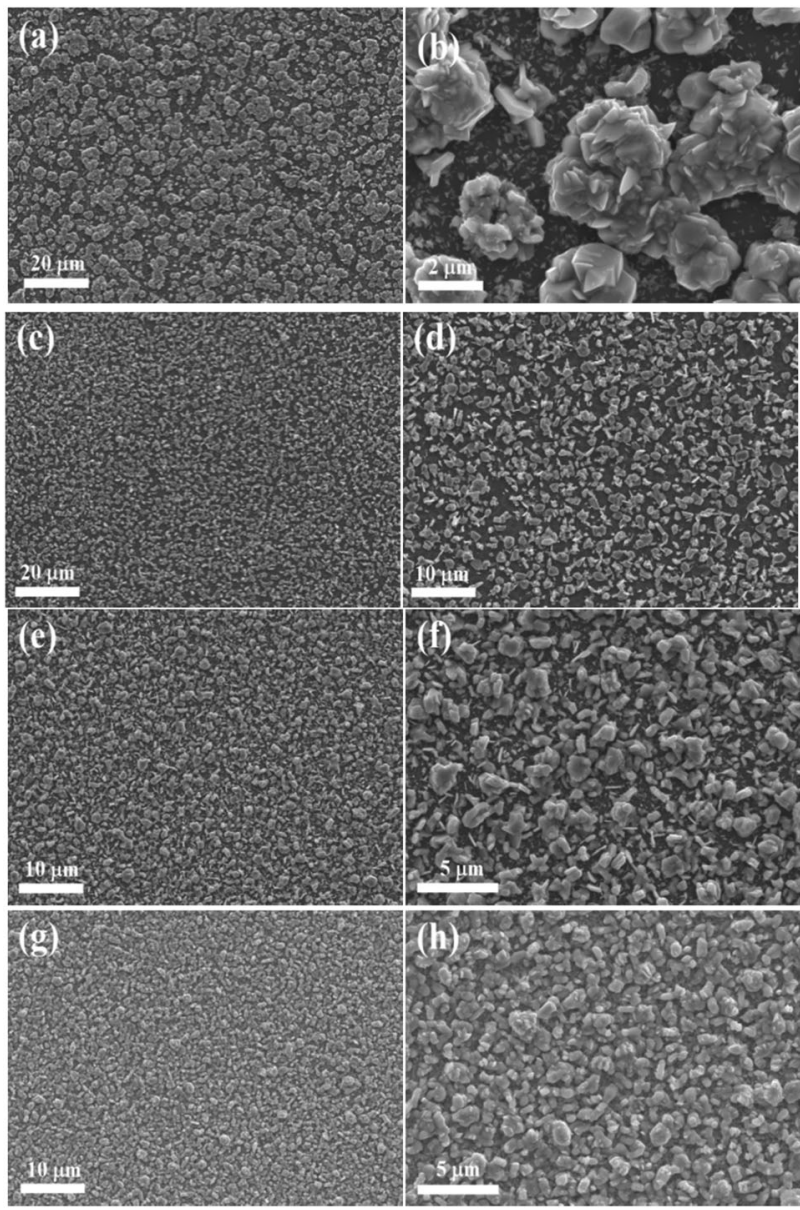

Fig. 11 Secondary electron mode SEM images (10 kV) of cobalt doped pyrite $\left(\mathrm{Co}_{x} \mathrm{Fe}_{1-x} \mathrm{~S}_{2}\right)$ thin films deposited at $350{ }^{\circ} \mathrm{C}$ on glass substrates by AACVD by varying ratio of complexes (1) and (2) at (a, b) $0.05 \mathrm{~mol} \%$, (c, d) $0.10 \mathrm{~mol} \%$, (e, f) $0.15 \mathrm{~mol} \%$, and $(\mathrm{g}, \mathrm{h}) 0.20 \mathrm{~mol} \%$.

doping (Fig. 12(a) and (b)), granular crystallites with an average size of $0.5 \mu \mathrm{m}$ on glass substrates at $0.30 \mathrm{~mol} \%$ of the copper dopant (Fig. 12(c) and (d)) and rhombohedral crystallites were deposited with average size $250 \mathrm{~nm}$ at $0.30 \mathrm{~mol} \%$ of zinc doping (Fig. 12(e) and (f)).

EDX spectroscopy of $\mathrm{M}_{x} \mathrm{Fe}_{1-x} \mathrm{~S}_{2}$ films deposited at differing ratios of complexes (mol\% of transition metal) confirm that the transition metals are incorporated into pyrite, consistent with the observations made by p-XRD (Fig. S2-S5, ESI\$).

AFM analysis of transition metal doped pyrite $\left(\mathrm{M}_{x} \mathrm{Fe}_{1-x} \mathrm{~S}_{2}\right)$ thin films shows the presence of uniform and crack-free surfaces (Fig. 13). The average crystallite heights is 200$400 \mathrm{~nm}, 33-182 \mathrm{~nm}, 130-100 \mathrm{~nm}$ and $120-140 \mathrm{~nm}$ for 0.05 $\mathrm{mol} \%$ and $0.30 \mathrm{~mol} \%$ transition metals $(\mathrm{Co}, \mathrm{Ni}, \mathrm{Cu}, \mathrm{Zn})$ doped pyrite $\left(\mathrm{M}_{x} \mathrm{Fe}_{1-x} \mathrm{~S}_{2}\right)$ thin films by using precursors (1) and (2), (3), (4) \& (5) respectively. This analysis also confirms the formation of nanocrystalline material in $0.30 \mathrm{~mol} \%$ doped zinc pyrite thin films where the particle size ranges between 20 to $50 \mathrm{~nm}$. The AFM images of the $\left(\mathrm{M}_{x} \mathrm{Fe}_{1-x} \mathrm{~S}_{2}\right)$ thin films show narrow particle size distribution and a uniform coverage of the substrate.
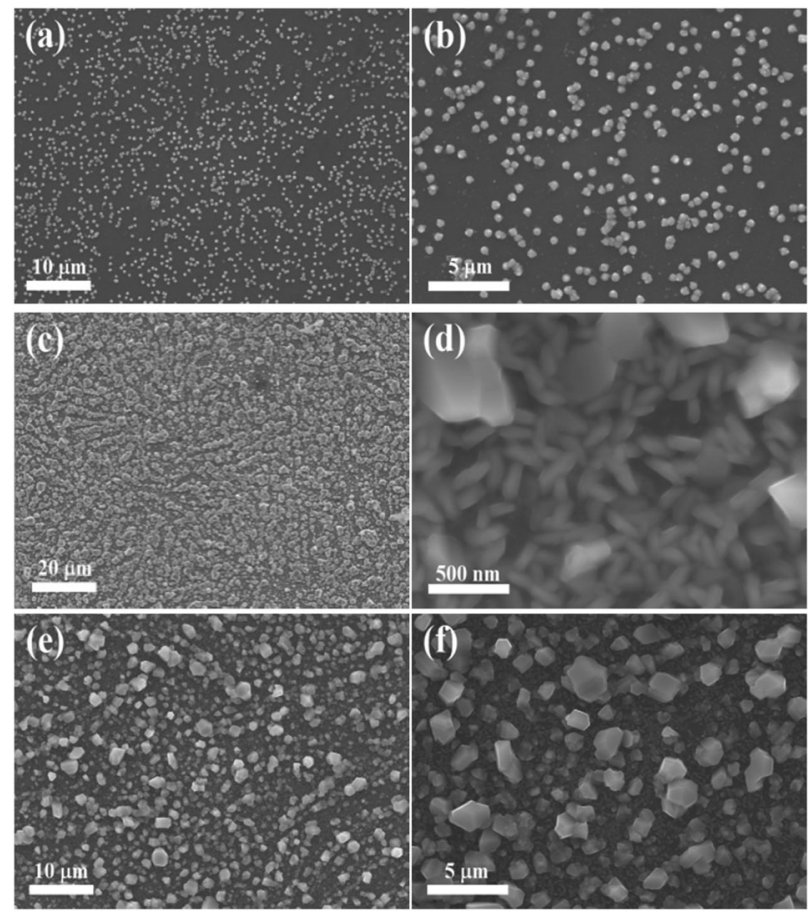

Fig. 12 Secondary electron mode SEM images $(10 \mathrm{kV})$ of transition metal doped pyrite $\left(\mathrm{M}_{x} \mathrm{Fe}_{1-x} \mathrm{~S}_{2}\right)$ thin films deposited at $350{ }^{\circ} \mathrm{C}$ on glass substrates by AACVD from complexes (a, b) (1) and (3), (c, d) (1) and (4), (e, f): (1) and (5). (a)

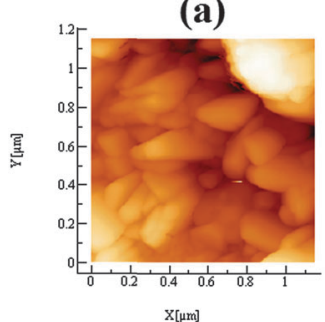

(c)

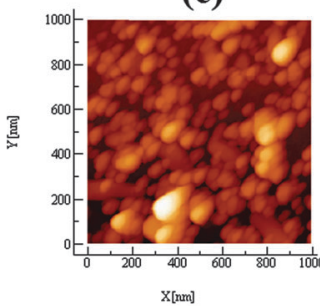

(b)
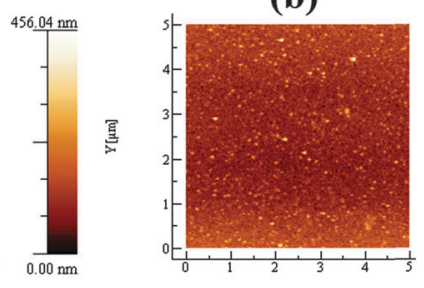

$\mathrm{X}[\mathrm{m} \mathrm{m}]$

(d)
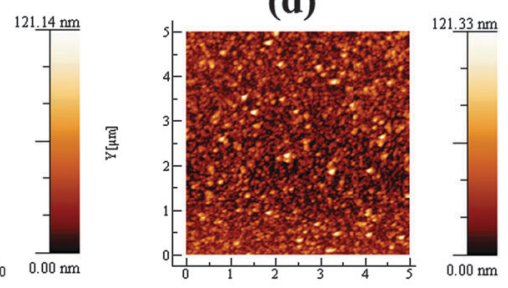

$\mathrm{x}[\mu \mathrm{m}]$
Fig. 13 Height-profile AFM images of transition metal doped pyrite $\left(\mathrm{M}_{x} \mathrm{Fe}_{1-x} \mathrm{~S}_{2}\right)$ thin films deposited at $350{ }^{\circ} \mathrm{C}$ on glass substrates by AACVD from complexes (a) (1) and (2), (b) (1) and (3), (c, d) (1) and (5).

\section{Conclusion}

Iron, cobalt, nickel, copper and zinc complexes of diethyldithiocarbamate $\left(\mathrm{M}\left(\mathrm{S}_{2} \mathrm{CN}(\mathrm{Et})_{2}\right)_{n}\right][\mathrm{M}=\mathrm{Fe}(\mathrm{III}), \mathrm{Co}(\mathrm{III}), \mathrm{Ni}(\mathrm{II}), \mathrm{Cu}(\mathrm{II}), \mathrm{Zn}(\mathrm{II})$ and $n=2,3$ ) have been used as single source precursors for the deposition of iron pyrite $\left(\mathrm{FeS}_{2}\right)$ and transition metal doped iron pyrite $\left(\mathrm{M}_{x} \mathrm{Fe}_{1-x} \mathrm{~S}_{2}\right)$ thin films onto glass and ITO coated glass substrates by AACVD. TGA confirmed that all five complexes 
decomposed to their corresponding metal sulfides in a similar temperature range. The iron complex $\left[\mathrm{Fe}\left(\mathrm{S}_{2} \mathrm{CNEt}_{2}\right)_{3}\right](\mathbf{1})$ at $350{ }^{\circ} \mathrm{C}$ deposited single phase cubic $\mathrm{FeS}_{2}$ films with granular crystallites, whereas at $450{ }^{\circ} \mathrm{C}$ mixed phase pyrite and marcasite was deposited. The formation of an $\mathrm{M}_{x} \mathrm{Fe}_{1-x} \mathrm{~S}_{2}$ solid solution was confirmed by shift in diffraction peaks in the p-XRD pattern. Depending upon the type of substrate and precursor solution composition, various morphologies of the films can be obtained. We expect this simple and flexible approach can be used for the synthesis of other ternary semiconductor nanocrystalline thin films with desirable morphologies, compositions and properties.

\section{Acknowledgements}

SK thanks the Higher Education Commission of Pakistan for an IRSIP scholarship and the POB group (The University of Manchester, UK) for assistance with this research. SK is also grateful to Nanoscience and Catalysis Division (NS\&CD), National Centre for Physics (NCP) Islamabad, Pakistan for providing research facilities as a hosted researcher. This work was also funded by the UK Engineering and Physical Sciences Research Council Core Capability in Chemistry grant (EPSRC grant number EP/K039547/1).

\section{Notes and references}

1 R. Sun, M. Chan and G. Ceder, Phys. Rev. B: Condens. Matter Mater. Phys., 2011, 83, 235311.

2 M. Gong, A. Kirkeminde and S. Ren, Sci. Rep., 2013, 3, 2092.

3 J. Xia, J. Jiao, B. Dai, W. Qiu, S. He, W. Qiu, P. Shen and L. Chen, RSC Adv., 2013, 3, 6132-6140.

4 G. Lee and M. Kang, Curr. Appl. Phys., 2013, 13, 1482-1489.

5 A. Raturi, S. Waita, B. Aduda and T. Nyangonda, Renewable Energy, 2000, 20, 37-43.

6 M. Gong, A. Kirkeminde, N. Kumar, H. Zhao and S. Ren, Chem. Commun., 2013, 49, 9260-9262.

7 S. Bae, D. Kim and W. Lee, Appl. Catal., B, 2013, 134, 93-102. 8 S. Liu, M. Li, S. Li, H. Li and L. Yan, Appl. Surf. Sci., 2013, 268, 213-217.

9 Y. Bai, J. Yeom, M. Yang, S.-H. Cha, K. Sun and N. A. Kotov, J. Phys. Chem. C, 2013, 117, 2567-2573.

10 C. Wadia, A. P. Alivisatos and D. M. Kammen, Environ. Sci. Technol., 2009, 43, 2072-2077.

11 P. Kevin, D. J. Lewis, J. Raftery, M. A. Malik and P. O’Brien, J. Cryst. Growth, 2014, DOI: 10.1016/j.jcrysgro.2014.1007.1019.

12 D. J. Lewis, P. Kevin, O. M. Bakr, C. A. Muryn, M. A. Malik and P. O'Brien, Inorg. Chem. Front., 2014, 1, 577-598.

13 D. J. Lewis and P. O'Brien, Chem. Commun., 2014, 50, 6319-6321.

14 A. Ennaoui, S. Fiechter, C. Pettenkofer, N. Alonso-Vante, K. Büker, M. Bronold, C. Höpfner and H. Tributsch, Sol. Energy Mater. Sol. Cells, 1993, 29, 289-370.

15 A. Kirkeminde, R. Scott and S. Ren, Nanoscale, 2012, 4, 7649-7654.

16 J. Hu, Y. Zhang, M. Law and R. Wu, J. Am. Chem. Soc., 2012, 134, 13216-13219.
17 Q. Yu, S. Cai, Z. Jin and Z. Yan, Mater. Res. Bull., 2013, 48, 3601-3606.

18 P. Díaz-Chao, I. Ferrer and C. Sánchez, Thin Solid Films, 2008, 516, 7116-7119.

19 C. Ho, C. Huang and C. Wu, J. Cryst. Growth, 2004, 270, $535-541$.

20 W. Ding, X. Wang, H. Peng, Z. Peng and B. Dong, Mater. Res. Bull., 2013, 48, 4704-4710.

21 K. Büker, S. Fiechter, V. Eyert and H. Tributsch, J. Electrochem. Soc., 1999, 146, 261-265.

22 I. J. Ferrer, J. Ares and C. Sánchez, Solid State Phenom., 2001, 80, 281-286.

23 A. Diener, T. Neumann, U. Kramar and D. Schild, J. Contam. Hydrol., 2012, 133, 30-39.

24 J. Xia, X. Lu, W. Gao, J. Jiao, H. Feng and L. Chen, Electrochim. Acta, 2011, 56, 6932-6939.

25 S. Lehner, K. Savage and J. Ayers, J. Cryst. Growth, 2006, 286, 306-317.

26 R. Schieck, A. Hartmann, S. Fiechter, R. Könenkamp and H. Wetzel, J. Mater. Res., 1990, 5, 1567-1572.

27 Y. Tomm, R. Schieck, K. Ellmer and S. Fiechter, J. Cryst. Growth, 1995, 146, 271-276.

28 C. De las Heras and L. Bausá, J. Phys.: Condens. Matter, 1997, 9, 9483.

29 M. Deng, S. Shen, Y. Zhang, H. Xu and Q. Wang, New J. Chem., 2014, 38, 77-83.

30 B. Mao, Q. Dong, Z. Xiao, C. L. Exstrom, S. A. Darveau, T. E. Webber, B. D. Lund, H. Huang, Z. Kang and J. Huang, J. Mater. Chem. A, 2013, 1, 12060-12065.

31 I. Ferrer, F. Cabellero, C. De las Heras and C. Sanchez, Solid State Commun., 1994, 89, 349-352.

32 S. Lehner, N. Newman, M. Van Schilfgaarde, S. Bandyopadhyay, K. Savage and P. Buseck, J. Appl. Phys., 2012, 111, 083717.

33 J. Jiao, L. Chen, D. Kuang, W. Gao, H. Feng and J. Xia, RSC Adv., 2011, 1, 255-261.

34 A. A. El Halim, S. Fiechter and H. Tributsch, Electrochim. Acta, 2002, 47, 2615-2623.

35 N. Berry, M. Cheng, C. L. Perkins, M. Limpinsel, J. C. Hemminger and M. Law, Adv. Energy Mater., 2012, 2, 1124-1135.

36 P. Díaz-Chao, J. Ares, I. Ferrer and C. Sánchez, J. Mater. Sci., 2013, 48, 4914-4924.

37 S. Seefeld, M. Limpinsel, Y. Liu, N. Farhi, A. Weber, Y. Zhang, N. Berry, Y. J. Kwon, C. L. Perkins and J. C. Hemminger, J. Am. Chem. Soc., 2013, 135, 4412-4424.

38 M. Afzaal, D. J. Crouch, P. O’Brien, J. Raftery, P. J. Skabara, A. J. P. White and D. J. Williams, J. Mater. Chem., 2004, 14, 233-237.

39 M. Afzaal, K. Ellwood, N. L. Pickett, P. O'Brien, J. Raftery and J. Waters, J. Mater. Chem., 2004, 14, 1310-1315.

40 D. S. Boyle, A. Bayer, M. R. Heinrich, O. Robbe and P. O'Brien, Thin Solid Films, 2000, 361, 150-154.

41 T. C. Deivaraj, J.-H. Park, M. Afzaal, P. O'Brien and J. J. Vittal, Chem. Mater., 2003, 15, 2383-2391.

42 M. B. Hursthouse, M. A. Malik, M. Motevalli and P. O'Brien, Polyhedron, 1992, 11, 45-48. 
43 M. Lazell, P. O'Brien, D. J. Otway and J.-H. Park, J. Chem. Soc., Dalton Trans., 2000, 4479-4486.

44 M. Akhtar, A. L. Abdelhady, M. Azad Malik and P. O’Brien, J. Cryst. Growth, 2012, 346, 106-112.

45 Y. Li, M. A. Malik and P. O'Brien, J. Am. Chem. Soc., 2005, 127, 16020-16021.

46 P. S. Nair, T. Radhakrishnan, N. Revaprasadu, G. A. Kolawole and P. O'Brien, Chem. Commun., 2002, 564-565.

47 M. Akhtar, J. Akhter, M. A. Malik, P. O'Brien, F. Tuna, J. Raftery and M. Helliwell, J. Mater. Chem., 2011, 21, 9737-9745.

48 T. Trindade, P. O’Brien and X.-m. Zhang, Chem. Mater., 1997, 9, 523-530.

49 A. Adeogun, M. Afzaal and P. O'Brien, Chem. Vap. Deposition, 2006, 12, 597-599.

50 K. Ramasamy, M. A. Malik and P. O’Brien, Chem. Sci., 2011, 2, 1170-1172.

51 K. Ramasamy, V. L. Kuznetsov, K. Gopal, M. A. Malik, J. Raftery, P. P. Edwards and P. O'Brien, Chem. Mater., 2013, 25, 266-276.
52 J. B. Zimmerman, T. W. Starinshak, D. L. Uhrich and N. V. Duffy, Inorg. Chem., 1977, 16, 3107-3111.

53 S. Singhal, A. Garg and K. Chandra, J. Alloys Compd., 2007, 428, 72-78.

54 T. Leong, Pertanika, 1982, 5, 114-116.

55 V. Tomashik, Iron Systems, Part 2, Springer, 2008, pp. 673-711.

56 I. Ferrer, C. de la Heras and C. Sanchez, J. Phys.: Condens. Matter, 1995, 7, 2115.

57 V. Raghavan, J. Phase Equilib. Diffus., 2004, 25, 373-381.

58 Y.-H. A. Wang, N. Bao and A. Gupta, Solid State Sci., 2010, 12, 387-390.

59 V. Raghavan, J. Phase Equilib. Diffus., 2004, 25, 450-454.

60 V. Raghavan, J. Phase Equilib. Diffus., 2008, 29, 457.

61 S. Thangavel, S. Ganesan, S. Chandramohan, P. Sudhagar, Y. S. Kang and C.-H. Hong, J. Alloys Compd., 2010, 495, 234-237.

62 P. Abraitis, R. Pattrick and D. Vaughan, Int. J. Miner. Process., 2004, 74, 41-59. 